\title{
Efficiency of Acalypha wilkesiana (Muell Arg.) leaf oil extract applied as a biocide against Callosobruchus maculatus (F.) (Coleoptera: Bruchidae)
}

\section{Mercy Olayinka Oni}

Federal University of Technology. Department of Crop, Soil and Pest Management. P. M. B 704. Akure. Nigeria. Email: mercyyinka2007@yahoo.co.uk.

\begin{abstract}
The ethanolic oil extracts of Acalypha wilkesiana was assayed for its biotoxicity against the survival of Callosobruchus maculatus, immature stages, damage and seed weight-loss. The result was dosage and time of exposure dependent. The contact treatment revealed $A$. wilkesiana oil as an applicable biocide as it significantly $(\mathrm{p}<0.05)$ affect the survival rate, suppressed oviposition and adult emergence of $C$. maculatus, hence reduced seed damage and weight-loss in grains below economic injury level. Contact treatment were the most toxic with $\mathrm{LD}_{50}$ values of 3.97 and 5.85 at $72 \mathrm{~h}$, significantly lower $(\mathrm{p}<0.05)$ than fumigant values 4.16 and 6.04, suggesting its isolation for future biocide study to establish the dose and mode of action for commercialization in crop protection.
\end{abstract}

Keywords: Callosobruchus maculates; Acalypha wilkesiana; Biotoxicity; Biocide; Oviposition; Mortality.

\section{Introduction}

In spite of introduction of many agricultural control programs by government of countries all over the world to improve agriculture, the post harvest losses of agricultural produce is still putting the food security of many of the developing countries in jeopardy. Food security is an integral role of an effective post-harvest system to ensure
Received

February 3, 2019

Accepted

April 10, 2019

Released

April 30, 2019

Full Text Article

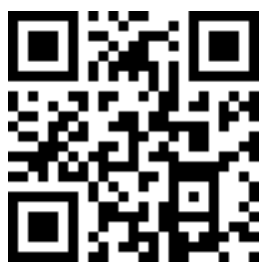

ORCID

(1) 0000-0002-3053-3567

Mercy Olayinka Oni 
Insect pests play an integral role in frustrating the food security of countries because their activities in storage are more pronounced than on the field and for any country to achieve food security it must be able to keep sizeable amount of agricultural produce in storage (Adamu, 2015).

In fact, Callosobruchus maculatus which is the most popular insect pest of cowpea has been noted of causing more than $50 \%-90 \%$ post harvest loss of cowpea (IITA, 1989; Oni, 2014; Ogungbite et al., 2014; Ajayi et al., 2015).

In decades, the use of conventional insecticides that pose threats to humans and environment; flora and faunas inclusive, was advocated as an effective means of insect control but recently their uses has dropped tremendously because of the downsides associated with them. In fact, their use in many developed countries has been banned (Isman, 2000). European countries recently barred the importation of many agricultural produce from Nigeria because of the DDVP (Dichlorovos) the country is using for the protection of their exported commodities (The Nigeria Punch July 31, 2015). Therefore, to comb for other methods of insect control becomes a subject of interest among the world food store managers. As alternatives, the use of natural pesticides becomes imperative in various forms as dusts, extracts, oils , indirect contact and fumes with little or no cost (Ukeh, 2009), have achieved striking results as crop protectants (Keita et al., 2001; Isman, 2008; Parugrug and Roxas, 2008).

With a view to ensure global food security, this study geared towards contributing to efforts of researchers to suppressing damage to food crops, through the discovery of essential components in Acalypha wilkesiana oil as sustainable biopesticides to investigate its contact and fumigant bioactivity against Callosobruchus maculatus in stored cowpea in the laboratory.

\section{Materials and methods}

\section{Cowpea seeds preparation}

The cowpeas seeds (ife-brown) cultivar used were sourced from the National Seed Service, Ibadan, Oyo State, Nigeria. The cowpea seeds were sorted and disinfested in freezer at $-18{ }^{\circ} \mathrm{C}$ for two weeks Koehler (2003) and air dried in the open laboratory to prevent mouldiness and kept in dry polytheme bags prior bioassay.

\section{Insect rearing}

The culturing population of Callosobruchus maculatus adults used for this study were obtained from an existing infested cowpea in the Post Graduate Entomology Laboratory of the Department of Crop, Soil and Pest Management Federal University of Technology, Akure Nigeria at temperature $28 \pm \quad 2{ }^{\circ} \mathrm{C}$ and $75 \pm \quad 5$ $\%$ relative humidity. The insects were reared in a perforated lid jar containing $200 \mathrm{~g}$ of uninfected cowpea seeds, to allow for oviposition and to obtain teneral adults $C$. maculatus for the assay.

\section{extraction \\ Plant materials and oil}

The leaves of $A$. wilkesiena used were obtained fresh from the open field around sports complex, Federal University of Technology, Akure. The leaves were air dried for 2 weeks in the open laboratory before milling into fine powder with binatone blender.

The oils were obtained by cold extraction, the powders were soaked in ethanol for $72 \mathrm{~h}$, in a glass jar. The mixture was rigorously mixed together and extract obtained were filtered with muslin cloth on the fourth day. The solvent was removed from the oil using a rotary evaporator. The oil was left opened to allow the traces of the solvent used to escape.

Contact with $A$. wilkesiana oil

The contact toxicity of $A$ wilkesiana oil at $1 \%, 2 \%, 3 \%, 4 \%$ and $5 \%$ 
concentrations $/ 20 \mathrm{~g}$ of cowpea seeds was investigated by exposing ten pairs of $0 \mathrm{~h}$ $24 \mathrm{~h}$ old adult male and female $C$. maculatus to the treated cowpea seeds in Petri dishes. Cowpea without plant oil treatment served as the control. The experiment was replicated three times, data on adult morality was assessed at $24 \mathrm{~h}, 48 \mathrm{~h}, 72 \mathrm{~h}$ and 96 hof application of oil.

Mortality was corrected using Abbott's formula (Abbott, 1925) and was subjected to probit analysis to estimate $\mathrm{LD}_{50}$ and $\mathrm{LD}_{95}$ with $95 \%$ confidence limit (Finney, 1971).

Data on the number of eggs laid was taken after 7 days of oviposition. The set up was left in the rearing chamber undisturbed for four weeks after which they were examined for adult emergence daily for 10 days. Percentage seed damage and weight loss was taken immediately after adult emergence data collection.

oil

\section{Fumigation with $A$. wilkesiana}

The fumigant toxicity of the oil extract was investigated against $C$. maculatus using the method of Zhou et al. (2012) as described by Yang et al. (2014) with little modifications. A cotton wool each fumigated with $1 \%, 2 \%, 3 \%, 4 \%$, and $5 \%$ concentration of was hung on the cover of a $1 \mathrm{~L}$ wide-mouth plastic containers, containing $20 \mathrm{~g}$ pairs of cowpea seeds. Ten pairs of one day old male and female $C$. maculatus were exposed to vapours of the oil for 4 days, while in the control set up, there was no plant material added. The experiment was replicated three times. The fumigation lasted for $96 \mathrm{~h}$. Data on adult mortality was recorded and corrected, using Abbott (1925) formula $\mathrm{LD}_{50}$ and $\mathrm{LD}_{95}$ were calculated using probit analysis (Finney, 1971). Number of eggs laid, percentage emerged adult, seeds damage and weight loss in seeds were calculated as described above and at the same mentioned environmental conditions.

\section{Repellency test}

The repellency test of the oil against $C$. maculatus was assayed using the method of preferential zone on filter paper by Yang et al. (2014) with some minor modifications. Petri-dishes, $9 \mathrm{~cm}$ each was lined with whatman filter paper and divided into half, different dosages of the oil were applied separately to one-half of the filter paper uniformly with a micropipette. The other half (control) was treated with $1 \mathrm{ml}$ of absolute ethanol. Both the treated half and the control half were air-dried to evaporate the solvent completely (30 s). A full disk was carefully remade by attaching the treated half to the negative control half with tape. Each reassembled filter paper after treatment with solid glue was placed in a Petri-dish with the same oriented in one of four different randomly selected directions to avoid any insecticidal stimuli affecting the distribution of insects. 20 starved adult cowpea weevils were placed at the center of the central zone of the divide and a cover was placed over the petridish. Insect count on each strip was recorded after $2 \mathrm{~h}, 4 \mathrm{~h}, 6 \mathrm{~h}, 8 \mathrm{~h}, 10 \mathrm{~h}, 12 \mathrm{~h}$ and $14 \mathrm{~h}$. The experiment was conducted in triplicate. The percentage repellency (PR) of each dose was calculated using the formula:

$$
\operatorname{PR}(\%)=\frac{\mathrm{Nc}-\mathrm{Nt}}{\mathrm{Nc}+\mathrm{Nt}} \times 100
$$

Where: Nc - Number of insects in the controlled zone (no - plant oil)

$\mathrm{Nt}$ - Number of insects in the treated zone (Plant oils available)

Pr - Percent repellency. 


\section{Statistical analysis}

Abbott (1925) formula was used to correct data on mortality counts using control mortality. All data were subjected to analysis of variance (ANOVA) at $\mathrm{p}<$ 0.05 . Means were separated with Duncan's Multiple Range Test. Mortality data and doses of A. wilkesiana were subjected to probit and log transformation respectively to determine the dose lethal to 50 and $95 \%$ of the insects $\left(L_{50}\right.$ and $\left.L D_{95}\right)$ (Finney, 1971). All analysis were carried out using SPSS 20.0 software package.

\section{Results}

\section{Contact toxicity to adults}

The effect of test plant oil on the survival of adult $C$. maculatus was concentration and period of exposure dependent. At $72 \mathrm{~h}$ post treatment $2-5 \%$ concentrations achieved above 50\% insect mortality, likewise all tested concentrations achieved above 60\% adult mortality, while $90 \%$ mortality was achieved at significantly greater doses (5\%) Table 1 . The number of eggs laid and the percentage adult emerged

Table 1. Effects of different concentrations of oil extracts of $A$. wilkesiana on mortality (\%) of $C$. maculatus infesting cowpea seeds.

\begin{tabular}{clccc}
\hline \multirow{2}{*}{ Concentration (\%) } & \multicolumn{4}{c}{ \% mortality in hours } \\
\cline { 2 - 5 } & \multicolumn{1}{c}{$\mathbf{2 4}$} & $\mathbf{4 8}$ & \multicolumn{1}{c}{$\mathbf{7 2}$} & \multicolumn{1}{c}{$\mathbf{9 6}$} \\
\hline 1 & $3.33 \pm 3.33^{\mathrm{ab}}$ & $13.33 \pm 3.33^{\mathrm{b}}$ & $30.00 \pm 5.77^{\mathrm{b}}$ & $60.00 \pm 5.77^{\mathrm{b}}$ \\
2 & $6.67 \pm 3.33^{\mathrm{ab}}$ & $16.67 \pm 3.33^{\mathrm{b}}$ & $56.67 \pm 3.33^{\mathrm{c}}$ & $66.67 \pm 3.33^{\mathrm{bc}}$ \\
3 & $6.67 \pm 3.33^{\mathrm{ab}}$ & $23.33 \pm 3.33^{\mathrm{bc}}$ & $63.33 \pm 3.33^{\mathrm{cd}}$ & $73.33 \pm 5.77^{\mathrm{c}}$ \\
4 & $10.00 \pm 0.00^{\mathrm{b}}$ & $30.00 \pm 5.77^{\mathrm{cd}}$ & $70.00 \pm 5.77^{\mathrm{cd}}$ & $76.67 \pm 3.33^{\mathrm{cd}}$ \\
5 & $13.33 \pm 3.33^{\mathrm{b}}$ & $36.67 \pm 3.33^{\mathrm{d}}$ & $73.33 \pm 6.67^{\mathrm{d}}$ & $90.00 \pm 5.77^{\mathrm{d}}$ \\
Control & $0.00 \pm 0.00^{\mathrm{a}}$ & $0.00 \pm 0.00^{\mathrm{a}}$ & $3.33 \pm 3.33^{\mathrm{a}}$ & $3.33 \pm 3.33^{\mathrm{a}}$ \\
\hline
\end{tabular}

Each data is mean \pm standard error of three replicates. Values followed by the same letter in the same column are not significantly $(\mathrm{p}<0.05)$ different from each other.

decreased with increasing concentration of $A$. wilkesiana oils. At all tested doses, the oil significantly $(\mathrm{P}<0.05)$ reduced seed damage and weight loss by $C$. maculatus and significantly different $(\mathrm{P}<0.05)$ from the controls Table 2.

Table 2. Effects of $A$. wilkesiana oil on No. of eggs laid and adult emergence of $C$. maculatus and its ability to cause seed damage and weight loss.

\begin{tabular}{cllll}
\hline \multirow{2}{*}{ Concentration (\%) } & \multirow{2}{*}{$\begin{array}{c}\text { No. of eggs } \\
\text { laid }\end{array}$} & \multicolumn{3}{c}{ Parameters in percentages (\%) } \\
\cline { 3 - 5 } & \multicolumn{1}{c}{ Adult emergence } & \multicolumn{1}{c}{ Damage } & Weight loss \\
\hline 1 & $44.33 \pm 2.33^{\mathrm{e}}$ & $27.87 \pm 1.77^{\mathrm{b}}$ & $11.53 \pm 0.82^{\mathrm{c}}$ & $1.40 \pm 0.32^{\mathrm{c}}$ \\
2 & $37.33 \pm 2.60^{\mathrm{d}}$ & $18.35 \pm 3.57^{\mathrm{a}}$ & $5.92 \pm 1.12^{\mathrm{b}}$ & $0.97 \pm 0.19^{\mathrm{bc}}$ \\
3 & $25.00 \pm 1.15^{\mathrm{c}}$ & $16.18 \pm 2.89^{\mathrm{a}}$ & $3.74 \pm 0.54^{\mathrm{ab}}$ & $0.73 \pm 0.04^{\mathrm{abc}}$ \\
4 & $18.33 \pm 0.88^{\mathrm{b}}$ & $12.62 \pm 1.20^{\mathrm{a}}$ & $2.80 \pm 0.54^{\mathrm{ab}}$ & $0.32 \pm 0.04^{\mathrm{ab}}$ \\
5 & $10.00 \pm 1.15^{\mathrm{a}}$ & $8.89 \pm 4.84^{\mathrm{a}}$ & $1.87 \pm 0.93^{\mathrm{a}}$ & $0.17 \pm 0.04^{\mathrm{a}}$ \\
Control & $89.00 \pm 1.73^{\mathrm{f}}$ & $45.77 \pm 2.83^{\mathrm{c}}$ & $37.69 \pm 1.64^{\mathrm{c}}$ & $26.40 \pm 0.40^{\mathrm{d}}$ \\
\hline
\end{tabular}

Each data is mean \pm standard error of three replicates. Values followed by the same letter in the same column are not significantly $(\mathrm{p}<0.05)$ different from each. 


\section{Fumigant toxicity to adults}

Regardless of the concentration of the oil insect mortality was not up to $50 \%$ at $48 \mathrm{~h}$ post treatment. Within $96 \mathrm{~h}$ of application. The $5 \%$ A. wilkesiana oil recorded the highest insect mortality (83.33\%), this effect was significantly (P $<0.05$ ) different from other tested dosages/exposure time. The mortality of the insect is concentration and period of exposure dependent. Fumigant effect of plant oils at $1 \%$ to $5 \%$ dosage on survival of $C$. maculatus was presented in Table 3.

Table 4 shows the effect of A. milkesiana oil on oviposition, adult emergence of $C$. maculatus and the ability to cause seed damage and weight loss of cowpea seeds. Oviposition and adult emergence of the insect reduced with increase in the oil concentration. At all tested doses, the oil significantly $(P<0.05)$ reduced number of egges laid, percentage adult emerged, seed damage and weight loss by C. maculatus when compared to the control having highest values on the four parameters observed. However the treatments were significantly different $(\mathrm{P}<0.05)$ from the control.

Table 3. Effects of fumigant toxicity of different Concentrations of oil extracts of $A$. wilkesiana on the survival (\% mortality) of $C$. maculatus infesting cowpea seeds.

\begin{tabular}{cllll}
\hline \multirow{2}{*}{ Concentration (\%) } & \multicolumn{4}{c}{ \% mortality in hours } \\
\cline { 2 - 5 } & \multicolumn{1}{c}{$\mathbf{2 4}$} & $\mathbf{4 8}$ & \multicolumn{1}{c}{$\mathbf{7 2}$} & \multicolumn{9}{c}{$\mathbf{6 6}$} \\
\hline 1 & $0.00 \pm 0.00^{\mathrm{a}}$ & $20.00 \pm 5.78^{\mathrm{b}}$ & $23.33 \pm 3.33^{\mathrm{b}}$ & $56.67 \pm 3.33^{\mathrm{b}}$ \\
2 & $3.33 \pm 3.33^{\mathrm{a}}$ & $26.67 \pm 3.33^{\mathrm{b}}$ & $33.33 \pm 3.33^{\mathrm{bc}}$ & $66.67 \pm 3.33^{\mathrm{bc}}$ \\
3 & $6.67 \pm 3.33^{\mathrm{a}}$ & $30.00 \pm 0.00^{\mathrm{bc}}$ & $46.67 \pm 3.33^{\mathrm{cd}}$ & $70.00 \pm 5.77^{\mathrm{c}}$ \\
4 & $10.00 \pm 5.77^{\mathrm{a}}$ & $40.00 \pm 5.77^{\mathrm{cd}}$ & $53.33 \pm 6.67^{\mathrm{d}}$ & $73.33 \pm 3.33^{\mathrm{cd}}$ \\
5 & $13.33 \pm 8.82^{\mathrm{a}}$ & $43.33 \pm 3.33^{\mathrm{d}}$ & $70.00 \pm 5.77^{\mathrm{e}}$ & $83.33 \pm 3.33^{\mathrm{d}}$ \\
Control & $0.00 \pm 0.00^{\mathrm{a}}$ & $0.00 \pm 0.00^{\mathrm{a}}$ & $3.33 \pm 3.33^{\mathrm{a}}$ & $3.33 \pm 3.33^{\mathrm{a}}$ \\
\hline
\end{tabular}

Each data is mean \pm standard error of three replicates. Values followed by the same letter in the same column are not significantly $(\mathrm{p}<0.05)$ different from each other.

Table 4. Effects of $A$. wilkesiana oil fume on No. of eggs laid and adult emergence of $C$. maculatus and its ability to cause seed damage and weight loss.

\begin{tabular}{ccccc}
\hline \multirow{2}{*}{ Concentration (\%) } & \multicolumn{4}{c}{ Parameters are in percentages (\%) } \\
\cline { 2 - 5 } & $\begin{array}{c}\text { No. of eggs } \\
\text { laid }\end{array}$ & $\begin{array}{c}\text { Adult } \\
\text { emergence }\end{array}$ & \multicolumn{1}{c}{ Damage } & \multicolumn{1}{c}{ Weight loss } \\
\hline 1 & $68.00 \pm 2.65^{\mathrm{d}}$ & $37.81 \pm 1.45^{\mathrm{c}}$ & $26.19 \pm 0.70^{\mathrm{d}}$ & $5.23 \pm 0.073^{\mathrm{d}}$ \\
2 & $58.33 \pm 1.45^{\mathrm{c}}$ & $25.25 \pm 2.12^{\mathrm{b}}$ & $14.97 \pm 1.19^{\mathrm{c}}$ & $3.78 \pm 0.09^{\mathrm{c}}$ \\
3 & $53.33 \pm 1.45^{\mathrm{c}}$ & $22.42 \pm 1.56^{\mathrm{ab}}$ & $12.27 \pm 1.30^{\mathrm{bc}}$ & $3.38 \pm 0.09^{\mathrm{bc}}$ \\
4 & $45.00 \pm 1.53^{\mathrm{b}}$ & $20.78 \pm 2.11^{\mathrm{ab}}$ & $9.20 \pm 0.97^{\mathrm{ab}}$ & $2.97 \pm 0.12^{\mathrm{b}}$ \\
5 & $39.00 \pm 1.53^{\mathrm{a}}$ & $15.65 \pm 3.49^{\mathrm{a}}$ & $6.14 \pm 1.13^{\mathrm{a}}$ & $2.13 \pm 0.12^{\mathrm{a}}$ \\
Control & $89.00 \pm 1.73^{\mathrm{e}}$ & $45.77 \pm 2.83^{\mathrm{d}}$ & $42.18 \pm 2.07^{\mathrm{e}}$ & $26.40 \pm 0.40^{\mathrm{e}}$ \\
\hline
\end{tabular}

Each data is mean \pm standard error of three replicates. Values followed by the same letter in the same column are not significantly $(\mathrm{p}<0.05)$ different from each other. 


\section{Lethal dosage $\left(\mathrm{LD}_{50}\right)$ and $\left(L D_{95}\right)$ of oil in C. maculatus at $72 \mathrm{~h}$}

The $\mathrm{LD}_{50}$ and $\mathrm{d}_{95}$ values obtained in this study (Table 5) were very little. Contact treatment of the oil appeared most effective against the adult insect than the fumigant treatment of the oil, as it recorded only $3.97 \%$ and $5.85 \%$ oil dosage to achieve $50 \%$ and $95 \%$ adult mortality within $72 \mathrm{~h}$ of application, compared to $4.16 \%$ and $6.04 \%$ required for fumigant toxicity. The chi-square value of the treatments also reflected the level of their effectiveness as they recorded values above 1.98 . Furthermore, their effects were significant as reflected in the Table 5 . The slope and intercept of the treatments showed that the treatments are very effective as their values are very low.

Table 5. Lethal doses of $A$. wilkesiana oil on $C$. maculatus at $72 \mathrm{~h}$ of application.

\begin{tabular}{lcccccc}
\hline Treatment & $\begin{array}{c}\text { Slope } \\
(\mathbf{\pm S E})\end{array}$ & $\begin{array}{c}\text { Intercept } \\
\mathbf{( \pm S E )}\end{array}$ & $\mathbf{X}^{\mathbf{2}}$ (df) & $\begin{array}{c}\text { LD } \\
(\mathbf{9 5} \% \mathbf{F L})\end{array}$ & $\begin{array}{c}\text { LD95 } \\
(\mathbf{9 5 \%} \text { FL) }\end{array}$ & Significant \\
\hline Contact & $0.42 \pm 0.12$ & $-0.50 \pm 0.06$ & $482.885(16)$ & $3.97(3.88-4.23)$ & $5.85(4.93-6.05)$ & 0.0001 \\
Fumigant & $0.12 \pm 0.11$ & $-0.07 \pm 0.06$ & $361.347(16)$ & $4.16(3.98-4.75)$ & $6.04(5.89-7.74)$ & 0.0001 \\
\hline
\end{tabular}

Note: LD: lethal dosage; SE: standard error; $x^{2}$ : Chi-square; df: degree of freedom; FL: Fiducial limits.
Repellent
action
of

\section{A. wilkesiana oil to $C$. maculatus}
The various concentration of $A$. wilkesiana oil showed different levels of repellence to $C$. maculatus at different periods of exposure. The $5 \%$ dose
recorded the highest repellence of $83.33 \%$ at $14 \mathrm{~h}$ after application while $1 \%$ dose recorded the lowest repellence of $16.67 \%$ at $2 \mathrm{~h}$ after application as shown in Table 6 and each was significantly different from others.

Table 6. Repellent activity (\%) of $A$. wilkesiana oil against adult $C$. maculates.

\begin{tabular}{cccccccc}
\hline \multirow{2}{*}{$\begin{array}{c}\text { Conc. } \\
\text { (\%) }\end{array}$} & \multicolumn{7}{c}{ \% repellent (h) } \\
\cline { 2 - 8 } & $\mathbf{2}$ & $\mathbf{4}$ & $\mathbf{6}$ & $\mathbf{8}$ & $\mathbf{1 0}$ & $\mathbf{1 2}$ & $\mathbf{1 4}$ \\
\hline 1 & $16.67 \pm 3.33^{\mathrm{a}}$ & $23.33 \pm 3.33^{\mathrm{a}}$ & $30.00 \pm 5.77^{\mathrm{a}}$ & $33.33 \pm 3.33^{\mathrm{a}}$ & $53.33 \pm 3.33^{\mathrm{a}}$ & $56.67 \pm 3.33^{\mathrm{a}}$ & $56.67 \pm 3.33^{\mathrm{a}}$ \\
2 & $20.00 \pm 0.00^{\mathrm{a}}$ & $30.00 \pm 5.77^{\mathrm{ab}}$ & $36.67 \pm 3.33^{\mathrm{ab}}$ & $40.00 \pm 5.77^{\mathrm{ab}}$ & $46.67 \pm 3.33^{\mathrm{ab}}$ & $56.67 \pm 3.33^{\mathrm{a}}$ & $63.33 \pm 3.33^{\mathrm{ab}}$ \\
3 & $23.33 \pm 6.67^{\mathrm{ab}}$ & $33.33 \pm 3.33^{\mathrm{ab}}$ & $40.00 \pm 0.00^{\mathrm{ab}}$ & $43.33 \pm 3.33^{\mathrm{ab}}$ & $56.67 \pm 3.33^{\mathrm{bc}}$ & $60.00 \pm 5.77^{\mathrm{ab}}$ & $70.00 \pm 5.77^{\mathrm{ab}}$ \\
4 & $26.67 \pm 3.33^{\mathrm{ab}}$ & $36.67 \pm 3.33^{\mathrm{ab}}$ & $43.33 \pm 8.82^{\mathrm{ab}}$ & $50.00 \pm 5.77^{\mathrm{bc}}$ & $63.33 \pm 3.33^{\mathrm{cd}}$ & $63.33 \pm 3.33^{\mathrm{ab}}$ & $73.33 \pm 3.33^{\mathrm{bc}}$ \\
5 & $33.33 \pm 3.33^{\mathrm{b}}$ & $43.33 \pm 6.67^{\mathrm{c}}$ & $46.67 \pm 3.33^{\mathrm{c}}$ & $60.00 \pm 0.00^{\mathrm{c}}$ & $66.67 \pm 3.33^{\mathrm{d}}$ & $70.00 \pm 0.00^{\mathrm{b}}$ & $83.33 \pm 3.33^{\mathrm{c}}$ \\
\hline
\end{tabular}

Each data is mean \pm standard error of three replicates. Values followed by the same letter in the same column are not significantly $(\mathrm{p}<0.05)$ different from each other.

\section{Discussion}

Contact and fumigant bioactivity of $A$. wilkesiana oil extracts on survival and immature stages of $C$. maculatus as well as damage to seeds and weight loss was investigated. In a bid to identify the chemical components of biotoxic properties was characterized.
The result obtained in this study showed that $A$. wilkesiana oil extract have effective insecticidal properties as it significantly affected the survival rate, suppressed oviposition and percentage adult emergence of $C$. maculatus and as well affected the ability of the insect to cause damage and weight loss of the protected cowpea seeds. The ability of 
the oil to effect high mortality of the insect, low oviposition rate and low adult emergence varied with the examined concentration of the oil extract. Likewise in a study conducted by Ajayi et al. (2018) investigated combined toxicity of chemical compounds of $M$. oleifera and $Z$. officinale oils were identified in cowpea seeds against $C$. chinensis. She reported that both oils to a moderate extent was effective at suppressing the number of eggs, number of adults emerged, giving suggestive clues on their usage to suppress bruchid population below economic injury level should the need arise.

The high mortality of $C$. maculatus recorded by the oil of this plant could be due to inability of the insect to feed on the protected cowpea seed. Despite adult $C$. maculatus does not eat they can live for longer period if provided with honey or sugary materials. Therefore, insect mortality recorded by the oil indicated that, the oil had no sugary substance that can serve as food for the insect and thereby lead to the starvation of the insect. Also, botanical based insecticides have been noted to have negative effect on respiratory organ of insects leading to hyperactivity and convulsion and total knockdown of insects (Schmutter, 2002; Zibaee, 2011; Rajashekar et al., 2014).

Therefore, the effect of the oil on adult survival could be due to blockage of spiracles of the insect which resulted to asphyxiation and thus causing respiratory impairment which probably affected metabolism and consequently other systems of the body of the bruchids, Osisogwu and Agbakwu, 1987: Onolemhem and Ogiangbe, 1991: Lale and Abdulrahaman, 1999). In a similar vein, Leatemia and Isman (2004), Adebiyi and Tedela (2012) as well as Ogungbite et al., (2014) reported that oils of botanicals were found to effect high mortality of $C$. maculatus and other stored product insect pest. The peculiarity of this study showed that oil extract of $A$. wilkesiana exhibited considerable degree of toxicity on number of eggs laid by C. maculatus, indicated that the oil had significant effect on the oviposition rate and adult emergence of the insect. The degree of toxicity varied between oil contact and fumigant tests as shown on oviposition and adult emergence of the insect, when compared to the controls. The low rate of oviposition of the insect indicated that the oil extract must have caused low mating communication between the male and female $C$. maculates (Oni, 2009).

As revealed by $L_{50}$ and $L D 95$ values, contact treatment were more toxic to $C$. maculatus than fumigant treatment. This may be attributed to the direct contac.t of all chemical components of insecticidal properties to the body wall of the weevils. Also, the low oviposition rate could be due to high mortality of the insect which resulted in low mating period that subsequently lead to low number of egg laid (Yusuf, 2009; Ashamo et al., 2013). Zibaee (2011) and Isman (2006) stated that botanical insecticides apart from having antifeedant effect on insects could also cause incomplete ecdysis in young insects and sterility in adult female insects. Therefore, the low oviposition rate implies that the oil must have caused sterility of the adult female C. maculatus.

Furthermore, the low rate adult emergence could be due to inability of egg laid by the insect to hatch into the larvae stage. The few larvae of the insect emerged may be unable to drop off their exoskelecton that remained connected to the posterior part of their abdomen (Oigiangbe et al., 2010; Adeyemo et al., 2013). In addition, the low oviposition rate recorded by the insect could also have caused the low rate of adult emergence. Obembe and Ogungbite (2016) suggested that botanical oils do block the chorion of insect's egg and thereby prevents the emergence of adult insects or lead to deformation of the insect larvae. The result of this study showed that the oviposition rate of the 
insect was dependent on mortality rate of the insect while weight loss of the seed was also dependent on adult emergence of the beetle. The result of this research acquiesced with the findings of Yusuf (2009), Ileke and Olotuah (2012), Ashamo et al. (2013), Oni (2014), Oni et al. (2016) in which botanical oils and powders were found to significantly reduced or prevented the emergence of adult C. maculatus. Low grain damage, weight loss and weevil perforation index was recorded in this work. This implies low feeding habit of the insect larvae which could have caused high seed damage, weight loss and subsequent high weevil perforation index. This agreed with the report of Akinneye and Oyeniyi (2016) in which the powder of some botanicals was found to affect the ability of Sitotroga cerealella to cause damage and weight loss of paddy rice.

Ikewuchi et al. (2009) reported the presence of flavonoids, alkaloids and tannins in the extract of $A$. wilkesiana. These phytochemicals have been reported of displaying different insecticidal efficacy against wide range of insect pests. They are being reported of disrupting life cycle of insects by causing high mortality rate of insect (Adonu et al., 2013; Yang et al., 2006). Therefore, the high mortality rate, low oviposition rate, low adult emergence, low seed damage and seed weight loss could be due to the presence of the phytochemicals present in the oil of $A$. wilkesiana.

Active compounds found present in the leaf extract of $A$. wilkesiana reported to be insecticidal in nature and are all alkaloids (Yang et al., 2006).

\section{Conclusion}

In conclusion, the oil of $A$. wilkesiana used in this work has proven insecticidal against cowpea beetle, C. maculatus. Nevertheless, the insecticidal potential of this plant oil depended on the concentration of the oil and the period of application. The result showed that the oil had contact toxicity effects on the oviposition and adult emergence of the insect as well as the ability of the insect to cause seed damage and weight loss compared to its fumigant toxicity. In addition, different active compounds were found in the oil extract of the plant. This could be synthesized for commercialization of the oil extract as crop protectants. In this respect, additional studies are needed to determine role of all active oil components in the immunity of the insects and possible effects on mammals.

\section{Conflict of interests}

The author declares that there are no conflicts of interest.

\section{References}

Abbott, W. S. A method for computing the effectiveness of an insecticide. Journal of Economic Entomology, v. 18, p. 265-267, 1925.

Adamu, A. Role of food security in achieving national security. The Punch, v. 39, p. 24, 2015.

Adebiyi, A. O.; Tedela, P. O. Pesticidal effects of extracts of Barbula indica on Callosobruchus maculatus (Coleoptera Bruchidae). Nature Science, v. 10, no. 9, p. 113-115, 2012.

Adeyemo, A. C.; Ashamo, M. O.; Odeyemi, O. O. Aframomum melegueta: A potential botanical (Walp.) with Newbouldia laevis (Seem.) extracts against infestation by Callosobruchus maculatus (Fabricius). Archive of Phytopathology and Plant Protection, v. 46, no. 11, p. 1295-1306, 2013.

Adonu, C. C.; Enwa, F. O.; Gugu, T. H.; Ugwu, K. O.; Esimone, C. 0.; Attama, A. A. In vitro evaluation of the combined effects of methanol extracts from Cassytha filiformis and Cleistopholis patens against Pseudomonas aeruginosa and Escherichia coli. International Journal of Advanced Research, v. 1, no. 5, p. 152-158, 2013.

Ajayi, O. E.; Balusu, R.; Morawo, T. O.; Zebelo, S.; Fadamiro, H. Semiochemical modulation of host preference of Callosobruchus 
maculatus on legume seeds. Journal of Stored Products Research, v. 63, p. 31-37, 2015.

Ajayi, O. E.; Oladipupo S. O.; Jegede. O. J. Comparative and synergistic influence of extracts of two tropical plants on activity of the cowpea weevil, Callosobruchus maculates. Medicinal Plant Research, v. 8, no. 8, p. 6073, 2018. https://doi.org/10.5376/mpr.2018 .08 .0008

Akinneye, J. O.; Oyeniyi, E. A. Insecticidal efficacy of Cleistopholis patens (Benth) against Sitotroga cerealella Olivier (Lepidoptera: Gelechiidae) infesting rice grains in Nigeria. Journal of Crop Protection, v. 5, no. 1, p. 1-10, 2016.

Ashamo, M. O.; Odeyemi, 0. 0.; Ogungbite, 0. C. Protection of cowpea, Vigna unguiculata L. (Walp.) with Newbouldia laevis (Seem.) extracts against infestation by Callosobruchus maculatus (Fabricius). Archives of Phytopathology and Plant Protection, v. 46, p. 11, p. 1295-1306, 2013.

Finney, D. J. Probit analysis. Cambridge: Cambridge University Press, 1971.

IITA - International Institute of Tropical Agriculture. Annual Report 1988/89. Ibadan Nigeria: IITA, 1989.

Ikewuchi, J. C.; Ikewuchi, C. C.; Igboh, M. N. Chemical profile of Tridax procumbens Linn. Pakistan Journal of Nutrition, v. 8, no 5, p. 548-550, 2009.

Ileke, K. D.; Olotuah, O.F. Bioactivity Anacardium occidentale (L.) and Allium sativum (L.) powders and oil extracts against cowpea bruchid, Callosobruchus maculatus (Fab.) (Coleoptera: Chrysomelidae). International Journal of Biology, v. 4, no. 1, p. 96-103, 2012.

Isman, M. B. Plant essential oils for pest and disease management. Crop Protection, v. 19, no. 8/10, p. 603-608, 2000. https://doi.org/10.1016/S0261-2194(00) 00079-X

Isman, M. B. Botanical insecticides, deterrents and repellents in modern agriculture and an increasingly regulated world. Annual Review of Entomology, v. 51, p. 45-66, 2006.

Isman, M. B. Perspective botanical insecticides: for richer, for poorer. Pest
Management Science, v. 64, p. 8-11, 2008. http://doi.org/1002/ps.1470

Keita, S. M.; Vincent, C.; Schmit, J. P.; TianelBdanger, A. Efficacy of essential oil, Ocimum basilum (L.) and O. gratissium (L.) applied as insecticidal fumigant and powder to control Callosobruchus maculatus (F.) (Coleoptera: Bruchidae). Journal of Stored Product

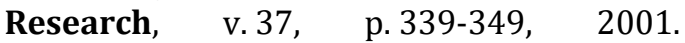
http://doi.org/10.1159/000212750

Lale, N. E. S.; Abdulrahman, H. T. Evaluation of neem, Azadirachta indica (A. Juss) seed oil obtained by different methods and neem powder for the management of Callosobruchus maculatus (F.) (Coleoptera: Bruchidae) in stored cowpea. Journal of Stored Products Research, v. 35, p. 135143, 1999.

Leatemia, J. A.; Isman, M. B. Efficacy of crude seed extracts of Annona squamosa against diamondback moth, Plutella xylostella L. in the greenhouse. International Journal of Pest Management, v. 50, p. 129-133, 2004.

Obembe, O. M.; Ogungbite, O.C. Entomotoxic effect of tobacco seed extracted with different solvents against Callosobruchus maculatus infesting stored cowpea. International Journal of Entomological Research, v. 1, no. 1, p. 22-26, 2016.

Ogungbite, O. C.; Odeyemi, O. O.; Ashamo, M. 0 . Powders of Newbouldia laevis as protectants of cowpea seeds against infestation by Callosobruchus maculatus (Fab.) for poor resource farmers. Octa Journal of Bioscience, v. 2, no. 1, p. 40-48, 2014.

Oigiangbe, O. N.; Igbinosa, I. B.; Tamo, M. Insecticidal properties of an alkaloid from Alstonia boonei De Wild. Journal of Biopesticides, v. 3, no. 1, p. 265-270, 2010.

Oni, M. O. Insecticidal activity of extracts from fruits of three local cultivars of pepper (Capsicum species) on cowpea seed beetle, (Callosobruchus maculates [Fabricius]) and maize weevil (Sitophilus zeamais (Motschulsky). Akure: Federal University of Technology, 2009. (Ph. D. thesis).

Oni, M. O. Entomotoxic efficacy of cayenne pepper, sweet pepper and long cayenne pepperoil extracts against Sitophilus zeamais infesting maize grain. Molecular Entomology, v. 5, no. 5, p. 37-44, 2014. 
Oni, M. O.; Ogungbite, O. C. Entomotoxicant potential of powders and oil extracts of three medicinal plants in the control of Sitophilus zeamais infesting stored maize. Journal of Plant and Pest Science, v. 2, no. 1, p. 8-17, 2015.

Oni, M. O.; Ogungbite, O. C.; Idoko, J. E. Effect of food type on tolerance of Callosobruchus maculatus from different geographical locations to the oil of Fagara xanthoxyloides. Global Journal of Agriculture Ecology, v. 4, no. 4, p. 168-175, 2016.

Parugrug, A. M.; Roxas A. C. Insecticidal action of five plants against maize weevil, Sitophilus zeamais Motsch. (Coleoptera: Curculionidae). King Mongkut's Institute of Technology Journal, v. 8, no. 1, p. 24-38, 2008.

Rajashekar, Y.; Raghavendra, A.; Bakthavatsalam, N. Acetylcholinesterase inhibition by biofumigant (Coumaran) from Leaves of Lantana camara in stored grain and household insect pests. BioMedical Research International, v. 2014, Article ID 187019, 2014. https://doi.org/10.1155/ 2014/187019

Ukeh, D. A. Repellant effects of five monoterpenoid odours against two stored products insects pests. Nigerian Journal of Entomology, v. 26, p. 11-19, 2009.

Yang, K.; Wang, C. F.; You, C. X.; Geng, Z. F.; Sun, R. Q.; Guo, S. S.; Du, S. S.; Liu, Z. L.; Deng,
Z. W. Bioactivity of essential oil of Litsea cubeba from China and its main compounds against two stored product insects. Journal of Asia-Pacific Entomology, v. 17, p. 459466, 2014.

Yang, Z.; Zhao, B.; Zhu, L.; Fang, J.; Xia, L. Inhibitory effects of alkaloids from Sophora alopecuroids on feeding, development and reproduction of Clostera anastomosis. Front for China, v. 1, no. 2, p. 190-195, 2006.

Yusuf, A. U. Comparative efficacy of different plant materials and Pirimiphos-methyl in the suppression of Callosobruchus maculatus F. (Coleoptera: Bruchidae) development and damage in cowpea seeds. Savannah Journal of Agriculture, v. 4, p. 45-53, 2009.

Zhou, H. Y.; Zhao, N. N.; Du, S. S.; Yang, K.; Wang, C. F.; Liu, Z. L.; Qiao, Y. J. Insecticidal activity of the essential oil of Lonicera japonica flower buds and its main constituent compounds against two grain storage insects. Journal of Medicinal Plants Research, v. 6, p. $912-917,2012$.

Zibaee, A. Botanical insecticides and their effects on insect biochemistry and immunity, pesticides in the world. In: Stoytcheva, M. (Ed.). Pesticides in the Modern World: Pest's control and pesticides exposure and toxicity assessment: Pests control and pesticides exposure and toxicity assessment. Rijeka, Croatia: InTec, 2011. p. 55-68. 